\title{
Kto tworzy największą encyklopedię świata? Analiza wewnętrznych danych Wikipedii
}

Patrycja Cybulska | Wydział Filologiczny, Uniwersytet Gdański

Słowa kluczowe:

encyklopedia, Wikipedia, autorzy, hasło, edytowanie

encyclopedia, Wikipedia, editors, article, edit

\section{Streszczenie}

Wikipedia uważana jest za największą encyklopedię świata. Niektórzy ją krytykują, inni wręcz przeciwnie - nie tylko ją popierają, ale także aktywnie uczestniczą w jej tworzeniu. Za sprawą nowych mediów status autorów haseł został wyrównany. Takie same prawo do dzielenia się wiedzą z innymi zyskali nie tylko eksperci, ale także wszyscy członkowie internetowej społeczności. Złamany został monopol na naukowców. Ponieważ wiadomo, że wśród autorów Wikipedii są zarówno profesorowie, jak i gimnazjaliści, ważną kwestią wydaje się próba ich charakterystyki. Analizie na podstawie wewnętrznych danych polskiej wersji językowej Wikipedii poddane zostaną zatem ich wykształcenie, wiek, płeć i liczba dokonywanych edycji. Wszystko po to, by obalić stereotyp, że tę największą encyklopedię świata tworzą nieprofesjonaliści.

Who creates the largest encyclopedia of the world?

\section{Analysis of Wikipedia internal data}

\section{Summary}

Wikipedia is considered to be the largest encyclopedia of the world. Some criticize it, others do not. Not only do they support it, they are also actively involved in its creation. With new media, the status of the entries contributors has been evened out. The same right to share knowledge with others has been gained not only by experts, but by all members of the online community. The monopoly on scientists was broken. Because it is known that the contributors of Wikipedia are both high school students and professors, it seems important to look at their characteristics. According to the internal data of the Polish language version of Wikipedia, they will be subject to their education, age, gender and number of editions. This is all about breaking the stereotype that this largest encyclopedia of the world is made up of non-professionals. 


\section{Wstęp}

Trudno dzisiaj znaleźć osobę, która o Wikipedii nigdy nie słyszała lub nigdy z niej nie korzystała. Na potrzeby niniejszego artykułu przeprowadzono krótką ankietę wśród rodziny i znajomych, w której zadano pytanie, czy korzystają z tej internetowej encyklopedii. Nie uzyskano ani jednej negatywnej odpowiedzi. Z obserwacji wynika zatem, że informacji na różne tematy szukają w Wikipedii zarówno uczniowie szkoły podstawowej, jak i nauczyciele, dziennikarze, lekarze, prawnicy, profesorowie wyższych uczelni, księża itd., czyli bardzo szerokie grono osób różnorodnych profesji. Skonstruowano zatem pytanie badawcze, kim są autorzy tej największej encyklopedii świata. Analizie poddano wiek, płeć, wykształcenie oraz liczbę dokonywanych edycji.

\section{O Wikipedii słów kilka}

Wikipedia sama siebie określa jako „wolną encyklopedię”, którą każdy może redagować (Wikipedia: Strona główna 2017). To sprawia, że wokół tego projektu tworzy się swoista społeczność wikipedystów - zarówno czytelników, jak i aktywnych edytorów, którzy zaczynają dzień od dokonania zmian w tym internetowym projekcie. Nowe media spowodowały, że autorytetów szuka się w Internecie. Już nie liczą się rodzice, nauczyciel, duchowny, ale na pierwszy plan wysuwa się właśnie przestrzeń online, wirtualna sieć. Autorytetami stają się blogerzy, vlogerzy czy czczeni na oficjalnych fanpage'ach celebryci. Z Internetu korzysta się, gdy potrzeba opinii o danym produkcie, gdy pragniemy porcji rozrywki oraz w poszukiwaniu informacji na jakiś temat, np. trapiących nas chorób, które to poszukiwania najczęściej kończą się... W Wikipedii.

To wszakże społeczność otwartej współpracy, czyli taka, w której ludzie

tworzą dobra publiczne, spontanicznie uczestnicząc we współpracy woluntarnej, bez jakichkolwiek finansowych korzyści. (...) Zachowania te znajdują się także pod bardzo silnym wpływem regulacji wytworzonych w ramach samych społeczności (Kobus, Jemielniak 2014).

Czym zatem jest Wikipedia? Po odpowiedź sięgnięto do samej Wikipedii.

Wikipedia - wielojęzyczna encyklopedia internetowa działająca w oparciu o zasadę otwartej treści. Funkcjonuje wykorzystując oprogramowanie MediaWiki (haw. Wiki - „szybko”, „prędko"), wywodzące się z koncepcji WikiWikiWeb, umożliwiające edycję każdemu użytkownikowi odwiedzającemu stronę i aktualizację jej treści w czasie rzeczywistym. Słowo Wikipedia jest neologizmem powstałym w wyniku połączenia wyrazów wiki i encyklopedia (Wikipedia, 2017).

Wikipedia powstała 15 stycznia 2001 r. Jej współzałożycielem był Jimmy Wales - amerykański ekonomista i przedsiębiorca (Wales 2005). Internetową encyklopedię stworzył ze swoim pracownikiem Larrym Sangerem. Nazwał ją „próbą stworzenia i rozpowszechnienia wielojęzycznej wolnej encyklopedii o najwyższym możliwym poziomie dla każdej osoby na Ziemi w jej własnym języku" (Wales 2017). 
W listopadzie 2015 r. Wikipedia miała ponad 36,9 mln artykułów we wszystkich wersjach językowych, w tym ponad $5 \mathrm{mln}$ artykułów w wersji anglojęzycznej oraz ponad 1,1 mln artykułów w wersji polskojęzycznej" (Wikipedia 2017). Obecnie angielskojęzyczna wersja Wikipedii zawiera ponad 2,9 mld słów. To ponad 60 razy więcej niż znana i doceniana Encyclopædia Britannica (Wikipedia, Size Comparisons 2017).

Polska wersja językowa Wikipedii została założona 26 września 2001 r. przez Krzysztofa Jasiutowicza, lekarza internistę, oraz Pawła Jochyma, fizyka. Pierwsze hasło dotyczyło reguły Titiusa-Bodego, według której,,średnie odległości planet od gwiazdy centralnej w Układzie Słonecznym spełniają dość dokładnie pewne proste arytmetyczne prawo" (Reguła Titiusa-Bodego 2017). Polskojęzyczna wersja Wikipedii znajduje się na 11 miejscu wśród wszystkich pozostałych wersji. Zawiera 1243272 haseł, 103 administratorów, ponad $50 \mathrm{mln}$ edycji haseł oraz 841658 użytkowników (List of Wikipedias 2017). Dla porównania, na pierwszym miejscu znajduje się wersja angielskojęzyczna z 5487519 hasłami, 1243 administratorami, ponad 913 mln edycji haseł oraz 31906080 użytkownikami (List of Wikipedias 2017).

\section{Autorzy Wikipedii}

Kiedy pytanie o autorstwo Wikipedii postawione zostaje jej użytkownikom, wielu z nich nie ma o tym pojęcia, nie obchodzi ich to, lub wydaje im się, że za tworzenie haseł odpowiedzialne są osoby o niskim poziomie wykształcenia. Przekonanie to potęguje anonimowość autorów Wikipedii, brak konkretnej osoby, najczęściej naukowca, odpowiedzialnego za treść. Jak zatem stwierdzić, kto tworzy największą encyklopedię świata? Z odpowiedzią przychodzi sama Wikipedia, która takie statystyki stworzyła. Autorów Wikipedii w polskiej wersji językowej zaprezentowano w tabeli 1.

\section{Tabela 1. Autorzy Wikipedii}

\begin{tabular}{|l|c|c|c|}
\hline \multicolumn{1}{|c|}{$\begin{array}{c}\text { Poziom wykształcenia } \\
\text { / nadany tytuł naukowy }\end{array}$} & $\begin{array}{c}\text { Zdobywający wykształcenie } \\
\text { / Otwarte przewody }\end{array}$ & $\begin{array}{c}\text { Przerwana } \\
\text { edukacja }\end{array}$ & $\begin{array}{c}\text { Ukończony } \\
\text { poziom edukacji }\end{array}$ \\
\hline Szkoła podstawowa & 27 & - & 7 \\
\hline Gimnazjum & 97 & - & 17 \\
\hline Zasadnicza Szkoła Zawodowa & - & - & 2 \\
\hline Technikum & 13 & - & 20 \\
\hline Liceum & 97 & - & 32 \\
\hline Szkoła policealna & 2 & - & 8 \\
\hline Studia licencjackie & 74 & - & 33 \\
\hline Studia inżynierskie & 42 & 18 & 285 \\
\hline Studia magisterskie & 110 & & 39 \\
\hline
\end{tabular}




\begin{tabular}{|l|c|c|c|}
\hline $\begin{array}{c}\text { Poziom wykształcenia } \\
\text { /nadany tytuł naukowy }\end{array}$ & $\begin{array}{c}\text { Zdobywający wykształcenie } \\
\text { / Otwarte przewody }\end{array}$ & $\begin{array}{c}\text { Przerwana } \\
\text { edukacja }\end{array}$ & $\begin{array}{c}\text { Ukończony } \\
\text { poziom edukacji }\end{array}$ \\
\hline Studia podyplomowe & 10 & - & 44 \\
\hline Doktoraty & 47 & - & 58 \\
\hline Habilitacje & - & - & 11 \\
\hline \multicolumn{2}{|l|}{ Profesorowie tytularni (tzw. belwederscy) } \\
\hline
\end{tabular}

Źródło: Wikipedia (Wikipedia: Statystyki/Wikipedyści według wykształcenia, dostęp: 01.09.2017).

Dane te pochodzą z 2014 r. Wśród autorów haseł w Wikipedii dużą grupę stanowią osoby z wykształceniem podstawowym i gimnazjalnym - łącznie 148 redaktorów, czyli 13,5\% wszystkich autorów internetowej encyklopedii. To o 2,4\% więcej niż grupa samodzielnych pracowników naukowych, która liczy 122 edytorów. Liczną grupę autorów Wikipedii stanowią także osoby w trakcie lub po zakończeniu studiów I stopnia to łącznie 188 redaktorów, czyli 17\% wszystkich autorów. Największa grupa to jednak wikipedyści w trakcie lub po studiach magisterskich - 413 osób, czyli 37,6\% wszystkich redaktorów Wikipedii. Powyższe dane obalają zatem stereotyp, że autorami haseł w Wikipedii są osoby o niskim poziomie wykształcenia.

Analizie poddano także wiek wikipedystów. Tutaj ponownie posłużono się danymi z Wikipedii, pochodzą one z maja 2017 r. Szczegółowo wiek wikipedystów w polskiej wersji językowej prezentuje tabela 2.

Tabela 2. Wikipedyści urodzeni w poszczególnych latach

\begin{tabular}{|r|r|r|r|r|r|r|r|r|r|r|r|r|r|r|r|r|r|}
\hline 1920 & 0 & 1930 & 0 & 1940 & 0 & 1950 & 1 & 1960 & 8 & 1970 & 10 & 1980 & 26 & 1990 & 50 & 2000 & 7 \\
\hline 1921 & 0 & 1931 & 1 & 1941 & 1 & 1951 & 1 & 1961 & 8 & 1971 & 7 & 1981 & 26 & 1991 & 63 & 2001 & 1 \\
\hline 1922 & 0 & 1932 & 0 & 1942 & 0 & 1952 & 5 & 1962 & 10 & 1972 & 12 & 1982 & 30 & 1992 & 53 & 2002 & 2 \\
\hline 1923 & 0 & 1933 & 0 & 1943 & 1 & 1953 & 2 & 1963 & 5 & 1973 & 19 & 1983 & 29 & 1993 & 57 & 2003 & 4 \\
\hline 1924 & 1 & 1934 & 1 & 1944 & 2 & 1954 & 4 & 1964 & 7 & 1974 & 11 & 1984 & 49 & 1994 & 45 & 2004 & 4 \\
\hline 1925 & 0 & 1935 & 1 & 1945 & 1 & 1955 & 5 & 1965 & 6 & 1975 & 28 & 1985 & 42 & 1995 & 31 & 2005 & 3 \\
\hline 1926 & 0 & 1936 & 1 & 1946 & 2 & 1956 & 4 & 1966 & 9 & 1976 & 19 & 1986 & 62 & 1996 & 26 & 2006 & 0 \\
\hline 1927 & 0 & 1937 & 1 & 1947 & 1 & 1957 & 5 & 1967 & 7 & 1977 & 29 & 1987 & 55 & 1997 & 23 & 2007 & 0 \\
\hline 1928 & 1 & 1938 & 1 & 1948 & 4 & 1958 & 8 & 1968 & 10 & 1978 & 19 & 1988 & 77 & 1998 & 23 & 2008 & 0 \\
\hline 1929 & 0 & 1939 & 1 & 1949 & 4 & 1959 & 5 & 1969 & 8 & 1979 & 31 & 1989 & 55 & 1999 & 11 & 2009 & 0 \\
\hline
\end{tabular}

Źródło: Wikipedia (Wikipedia: Statystyki: Wikipedyści według roku urodzenia, dostęp: 01.09.2017).

Powyższe dane wskazują, że najstarszy wikipedysta ma 93 lata (rok urodzenia 1924). Najmłodsi autorzy Wikipedii mają zaś 12 lat - 3 osoby (rok urodzenia 2005). Najwięcej natomiast jest wikipedystów w wieku 29 lat - to aż 77 osób (rok urodzenia 1988). 
Zgadza się to z poziomem ich wykształcenia - osoby przed 30 rokiem życia to najczęściej takie, które ukończyły studia magisterskie i rozpoczęły pracę, w tym przypadku również tę nad tworzeniem największej encyklopedii świata.

Po rozpoznaniu wykształcenia i wieku wikipedystów skonstruowano pytanie badawcze, kim są. Jako przykład posłużyło stworzone przez wikipedystów hasło „Chrześcijaństwo" ${ }^{\prime 2}$, które na początku września 2017 r. w polskojęzycznej Wikipedii liczyło 25 stron maszynopisu. Hasło powstało 12 września $2002 \mathrm{r}$. i od tamtej pory do teraz miało 1450 wersji. Łącznie pracowało nad nim 588 edytorów (Lista autorów i statystyki hasła "Chrześcijaństwo" 2017). Hasło miało także dyskusje 3 liczące 253 wersje, 583 strony maszynopisu i było edytowane przez 82 redaktorów (Lista autorów i statystyki strony dyskusji hasła "Chrześcijaństwo" 2017).

Trzech najbardziej aktywnych autorów hasła "Chrześcijaństwo" to: Vuvar1, Monika i Lukas3 (Lista autorów i statystyki hasła "Chrześcijaństwo” 2017). Vuvar1 edytował hasło 58 razy, co stanowi 4\% wszystkich edycji. Na jego stronie użytkownika znaleźć można następujący cytat: „«Znieważył mnie, walczył ze mną, ograbił i pokonał mnie». Kto myśl taką precz odrzuci, w tym zawiść sama wygaśnie. Zawsze tak było na świecie, że wrogość nic nie zwycięży wrogości, tylko miłość zawiść gasi, bo takie jest wieczne prawo", autorstwa Siddhārtha Gautamy. Wikipedysta ten zamieścił tam także swój adres mejlowy (zachowana oryginalna pisownia):,ffafuk57 maupa googlemail kropek com". Wiadomo o nim również, że oprócz języka polskiego posługuje się innymi językami: angielskim, niemieckim i rosyjskim. Dodatkowo zna terminologię stosowaną w językoznawstwie i w medycynie (Wikipedysta: Vuvar1, 2017).

Kolejnym wikipedystą, który dokonał największej liczby edycji omawianego hasła - 32, jest Monika. Na stronie tego użytkownika przeczytać można, że jest kobietą, a Wikipedię edytuje od 24 lutego 2003 r. Dodatkowo podaje swój adres IP (zachowana oryginalna pisownia): „Jeśli się nie moge lub nie chcę zalogowac mam ip - 62.179.13.22”. O wikipedystce tej wiadomo także, że oprócz języka polskiego posługuje się angielskim i włoskim. Dodatkowo zna terminologię używaną w religioznawstwie, jest sceptykiem, ateistą oraz lubi pić herbatę (Wikipedysta: Monika, 2017).

Trzecim z kolei wikipedystą w tej grupie jest Lukas3 z 28 edycjami hasła „Chrześcijaństwo". Na stronie użytkownika zamieścił on swoje zdjęcie oraz w następujący sposób wyjaśnił obecność w Wikipedii (pisownia oryginalna):,,Idea tworzenia Wolnej Encyklopedii bardzo spodobała mi się już od czasu przeczytania książki sf „Fundacja” autorstwa Isaaka Asimowa w której jest mowa o epokowym dziele jakim jest - Encyklopedia Galaktyczna, będącą swoistą skarbnicą wiedzy w czasie epoki upadku Imperium

\footnotetext{
2 Autorka tekstu bada pochodzące z Wikipedii hasło "Chrześcijaństwo” w pracy doktorskiej. Za pomocą metody badawczej, jaką jest analiza zawartości, analizuje zmiany hasła na przestrzeni lat, język wikipedystów oraz stawia tezę, że edytowanie Wikipedii to jeden z elementów kultury popularnej. Metodę analizy zawartości szerzej przedstawia Małgorzata Lisowska-Magdziarz (2004). 3 Oprócz dostępnego dla wszystkich użytkowników Wikipedii hasła, każda strona zaopatrzona jest także w stronę dyskusji. Służy ona do zgłaszania uwag, wymiany opinii oraz rozwiązywania konfliktów powstałych podczas tworzenia kolejnych edycji haseł (Pomoc: Strona dyskusji 2017).
} 
oraz środkiem do odrodzenia cywilizacji". O wikipedyście tym wiemy także m.in., że posługuje się językami polskim, angielskim i rosyjskim, „szuka równowagi między inkluzionizmem a delecjonizmem", solidaryzuje się z Tybetańczykami oraz używa OpenOffice.org (Wikipedysta: Lukas3 2017).

\section{Śmiało edytuj}

Edycja haseł w Wikipedii wymaga od autorów zastosowania określonych zasad. Mimo że hasłem, Ś́miało edytuj" ta internetowa encyklopedia zachęca do jej współtworzenia, a „nowi wikipedyści są bardzo mile widziani i chętnie witani, bo wszelki wkład merytoryczny jest podstawą rozbudowy Wikipedii i jej dalszego funkcjonowania" (Pomoc: Poradnik autora Wikipedii 2017), działania takie są jednak kontrolowane. Wikipedia to bowiem zorganizowana hierarchicznie struktura, chociaż encyklopedia ta nie lubi, kiedy mówi się o niej w ten sposób. Po każdej wprowadzonej zmianie wikipedysta wypełnia „pole opisu zmian”, informujące innych użytkowników „o charakterze dokonanych zmian” oraz które „jest bardzo użyteczne dla kontrolowania, czy ktoś nie próbował zwandalizować artykułu" (Pomoc: Poradnik autora Wikipedii 2017). Pełniący różne zadania wikipedyści decydują, co z daną zmianą zrobić. Sprawdzają m.in., czy spełnia ona warunek encyklopedyczności oraz czy wikipedysta powołał się na źródło - to podstawa przy tworzeniu treści tej internetowej encyklopedii. Jeśli spełnione zostaną wskazane warunki, edycja zostaje zaakceptowana. Istnieją jednak kwestie sporne, które powodują wymianę zdań wikipedystów, tworzą konflikt. Najczęściej dotyczy on m.in. polityki, seksu lub religii (Fichman, Hara 2014). Zgodnie z zasadami Wikipedii, aby dojść do porozumienia, wikipedyści muszą wypracować konsensus, czyli 2/3 głosów. Wymaga on od użytkowników Wikipedii „działania w dobrej wierze dla dokładnego określenia różnic w spojrzeniu na zagadnienie" (Wikipedia: Konsensus 2017). Jeśli nie udaje się wypracować konsensusu, wtedy użytkownicy Wikipedii rozpoczynają proces głosowania:

Zaleca się jasno określić zasady głosowania. Powinna być w sposób prosty i wyczerpujący przedstawiona propozycja, za którą, lub przeciw której uczestnicy będą głosować. Zazwyczaj przy głosowaniach nad propozycjami ustalane są progi, które powinna dana propozycja osiągnąć, aby być przyjęta: np. $80 \%$ za, czy $70 \%$ za. Jeżeli jest więcej niż jedna propozycja, można dać mniejszy próg (Wikipedia: Głosowania 2017).

Metoda ta wykorzystywana jest także przy nadawaniu uprawnień użytkownikom Wikipedii.

Jeżeli i głosowanie nie przyniesie zakładanego rezultatu, wtedy stosuje się rozwiązywanie konfliktów tzw. innymi metodami. To w kolejności: dialog, mediacje oraz postępowanie przed Komitetem Arbitrażowym. W przypadku mediacji wikipedyści mogą także powołać osobę, która będzie pomagała rozstrzygnąć konflikt (Wikipedia: Rozwiązywanie konfliktów 2017). 


\section{Role społeczne w Wikipedii}

Największa encyklopedia świata wszystkim użytkownikom przypisuje określone role. Za Dariuszem Jemielniakiem (2013: 60) przyjmuję następujący podział wikipedystów:

- steward,

- checkuser,

- rewizor,

- biurokrata,

- administrator,

- użytkownik uprawniony do szybkiego cofania zmian,

- zarejestrowany użytkownik,

- świeżo zarejestrowany użytkownik,

- niezarejestrowany użytkownik,

- zablokowany użytkownik.

Zablokowany użytkownik nie może dokonywać edycji, ponieważ została na niego nałożona blokada, np. w wyniku szkodliwych edycji, łamiących zasady projektu. Niezarejestrowany użytkownik to taki, który nie utworzył konta w Wikipedii, a jego edycje pojawiają się jako adres IP. Świeżo zarejestrowany użytkownik to ktoś dopiero rozpoczynający edytowanie największej encyklopedii świata. Te trzy opisane tutaj funkcje mają ograniczone uprawnienia. Pełne prawa do edytowania Wikipedii zgodnie z obowiązującymi zasadami uzyskuje dopiero zarejestrowany wikipedysta. Użytkownicy uprawnieni do szybkiego cofania zmian natomiast zajmują się m.in. wycofywaniem tzw. wandalizmów, czyli wpisów niezgodnych z zasadami Wikipedii. Ich obecność jest niezbędna do prawidłowego funkcjonowania projektu. Kolejne role przyznawane są w drodze głosowań. Ich wzajemną zależność przedstawia rysunek 2.

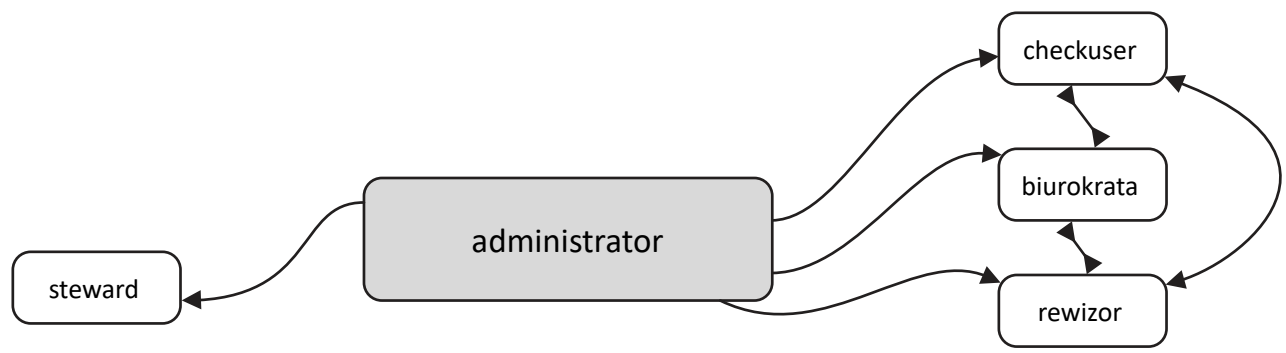

Rysunek 2. Role społeczne w Wikipedii

Źródło: Opracowanie własne.

Najważniejszą rolę społeczną pełnią stewardzi. Co roku wybiera ich ogólnoświatowa grupa aktywnych edytorów projektów Wikimedia ${ }^{4}$. Stewardzi mają najszerszy dostęp do wszystkich projektów oraz do wszystkich działań dowolnej grupy użytkowników.

4 Obecnie w Polsce działa 11 siostrzanych projektów Wikipedii. To m.in. zbiór podręczników, gazeta online oraz zbiór cytatów. 
Mogą m.in. usuwać konta, jak również wykonywać decyzje społeczności lub działać wedle własnego uznania, jednak nie powinni wykorzystywać swoich uprawnień w projektach, które edytują. Aby zostać stewardem, trzeba wcześniej pełnić rolę administratora oraz wykazać się dużym doświadczeniem, które jest oznaką zaufania wikipedystów (Jemielniak 2013: 62).

Następna grupa użytkowników Wikipedii to checkuserzy. Ich głównym zadaniem jest sprawdzanie adresów IP, tak by wykluczyć lub potwierdzić działania użytkowników dokonujących edycji z wielu kont. Aby pełnić tę funkcję, nie trzeba być administratorem, ale w praktyce wybierani są głównie zaufani administratorzy (Jemielniak 2013: 61-62).

Rewizorzy natomiast mają możliwość ukrywania edycji i nazw użytkowników, tak by w ramach trwającej dyskusji mogli zobaczyć je tylko stewardzi i rewizorzy (Jemielniak 2013: 62).

Zgodnie z zasadami Wikipedii, aby pełnić funkcję stewarda, checkusera lub rewizora, trzeba mieć ukończone 18 lat oraz podać swoje dane, przesyłając skany dokumentów do Wikimedia Foundation, nadzorującej Wikipedię oraz projekty z nią związane.

Kolejną rolą społeczną, jaką mogą pełnić wikipedyści, są biurokraci. Zajmują się m.in. przyznawaniem uprawnień administratora zarejestrowanym użytkownikom, jednak nie według uznania, a zgodnie z życzeniem społeczności. Dodatkowo mogą także zmieniać nazwy użytkowników oraz przechwytywać nieaktywne konta. Przez lata istnienia Wikipedii "osiągnięto już wystarczającą wydolność tej grupy”, dlatego wymagane jest bardzo duże poparcie społeczności, by utworzenie kolejnego stanowiska biurokraty było zasadne (Jemielniak 2013: 62).

Najbardziej liczną grupę wikipedystów o zwiększonych uprawnieniach stanowią natomiast administratorzy. To doświadczeni użytkownicy, którzy blokują lub odblokowują innych wikipedystów oraz usuwają lub przywracają artykuły. Dodatkowo mogą także całkowicie lub częściowo zabezpieczać je przed edycją. Aby zostać administratorem, należy posiadać około $80 \%$ poparcia społeczności oraz spełniać różne inne wymagania, np. utworzenie odpowiedniej liczby haseł i edycji, uczestnictwo w dyskusjach oraz przyjazność dla nowych użytkowników. Uprawnienia administratora nadawane są w drodze głosowań. To proces bardzo trudny, nazywany „krwawą łaźnią" lub „ścieżką zdrowia", ponieważ przyjmuje czasami „formę egzaminu sprawdzającego umiejętności kandydata (często przez zadawanie trudnych pytań) oraz osobistych przytyków i ośmieszających komentarzy, czynionych z zamiarem wyeksponowania jego wad (Jemielniak 2013: 71). Dlatego wiele osób z uczestnictwa w procesie PUA - przyznawania uprawnień administratora - po prostu rezygnuje.

W Wikipedii za edycję haseł odpowiedzialne są również przypisane zaawansowanym użytkownikom boty. To specjalne programy, który w sposób automatyczny np. poprawiają błędy ortograficzne (Pomoc: Poradnik autora Wikipedii 2017). 


\section{Wikipedia w Internecie}

Jak wynika z raportu Wikipedia i jej użytkownicy (Miotk 2017), opublikowanego 26 września 2017 r. przez organizację Polskie Badania Internetu, Wikipedia jest jedną z najpopularniejszych witryn internetowych w Polsce. W sierpniu 2017 r. zajęła 9 miejsce $w$ rankingu top 10 domen w polskim Internecie, z liczbą 12,8 $\mathrm{mln}$ użytkowników (Miotk 2017: 3). Autorka raportu wskazuje, że Wikipedię chętniej edytują mężczyźni niż kobiety - są autorami około $90 \%$ wszystkich haseł tej internetowej encyklopedii. Obie płcie natomiast równie często z niej korzystają (po 6,4 mln dla każdej płci) (Miotk 2017:10).

\section{Zakończenie}

Analiza wewnętrznych danych Wikipedii prowadzi do następujących wniosków na temat tego, kto tworzy tę największą internetową encyklopedię na świecie. Po pierwsze, edytowaniem artykułów w polskiej wersji językowej tej encyklopedii zajmują się w większości osoby, które ukończyły studia magisterskie. Obala to zatem stereotyp, że hasła tworzą ludzie niewykształceni. Średnio wikipedysta ma 29 lat, a zatem można powiedzieć, że najczęściej twórcami Wikipedii są młode osoby po studiach.

Po drugie, ilu użytkowników, tyle różnych zainteresowań i zajęć wikipedystów. Wiadomo o nich tyle, ile sami zechcą powiedzieć na stronach użytkowników. Posługują się różnymi językami, znają naukową terminologię, są osobami wierzącymi/ateista$\mathrm{mi}$, solidaryzują się z innymi narodami lub po prostu lubią pić herbatę. Wyniki analizy wskazują jednak, że hasła, np. związane z religią, nie zawsze tworzą osoby zaangażowane $w$ dany temat, co umożliwia spojrzenie na problem $z$ nowej perspektywy.

Po trzecie, mimo że Wikipedia zachęca swoich autorów do „śmiałego edytowania", nic w tej internetowej encyklopedii nie dzieje się bez kontroli. Nadzorowi poddawany jest każdy wpis, a autorzy pełnią określone role społeczne, od mniej do bardziej zaangażowanych. Część z nich przyznawana jest automatycznie, inne w drodze głosowań i dyskusji, tworząc swoistą „ścieżkę kariery" wikipedystów.

Po czwarte zaś, Wikipedia mało przystaje do świata naukowej kultury. W tej internetowej encyklopedii zapisano, że nie obowiązują jej sztywne reguły, a strony często modyfikowane są dla samej przyjemności, w oparciu o zdrowy rozsądek. A zatem Wikipedia stosuje się do zasad typowych dla świata kultury popularnej, w którym najważniejsze staje się to, co w swej istocie jest nieważne, ale za to intrygujące i zaskakujące. W kontekście tym stawiane są pytania, co z wiarygodnością tej internetowej encyklopedii i dlaczego, mimo braku sztywnych naukowych zasad, jest tak popularna? Odpowiedzi na te pytania to jednak temat na osobne rozważania. 


\section{Bibliografia}

Chrześcijaństwo, https://pl.wikipedia.org/wiki/Chrze\%C5\%9Bcija\%C5\%84stwo [dostęp: 28.08.2017]. Fichman P., Hara N., 2014, Global Wikipedia: International and Cross-Cultural Issues in Online Collaboration. Plymouth: Rowman \& Littlefield Publishers.

Jemielniak D., 2013, Życie wirtualnych dzikich. Netnografia Wikipedii, największego projektu współtworzonego przez ludzi. Warszawa: Poltext.

Kobus M., Jemielniak D., 2014, Ekonomia daru i społeczności otwartej współpracy - nowe kierunki badań społecznych, „E-mentor” nr 4 (56), http://www.e-mentor.edu.pl/artykul/index/numer/56/ id/1116 [dostęp: 16.08.2017].

Lisowska-Magdziarz M., 2004, Analiza zawartości mediów. Przewodnik dla studentów. Kraków: Uniwersytet Jagielloński.

Lista autorów istatystyki hasła "Chrześcijaństwo", https://xtools.wmflabs.org/articleinfo/pl.wikipedia. org/Chrze\%C5\%9Bcija\%C5\%84stwo [dostęp: 04.09.2017].

Lista autorów i statystyki strony dyskusji hasła "Chrześcijaństwo", https://xtools.wmflabs.org/articleinfo/pl.wikipedia.org/Dyskusja:Chrze\%C5\%9Bcija\%C5\%84stwo [dostęp: 08.09.2017].

List of Wikipedias, https://en.wikipedia.org/wiki/List_of_Wikipedias [dostęp: 04.10.2017].

Miotk A., 2017, Wikipedia i jej użytkownicy. Polskie Badania Internetu, http://pbi.org.pl/wp-content/ uploads/2017/09/2017-09-26-Wikipedia_analiza.pdf [dostęp: 25.09.2017].

Pomoc: Poradnik autora Wikipedii, https://pl.wikipedia.org/wiki/Pomoc:Poradnik_autora_Wikipedii [dostęp: 08.09.2017].

Pomoc: Strona dyskusji, https://pl.wikipedia.org/wiki/Pomoc:Strona_dyskusji [dostęp: 03.09.2017].

Reguła Titiusa-Bodego, https://pl.wikipedia.org/wiki/Regu\%C5\%82a_Titiusa-Bodego [dostęp: 04.10.2017].

Wales J., 2005, Wikipedia is an encyclopedia, https://lists.wikimedia.org/pipermail/wikipedia-l/ 2005-March/020469.html [dostęp: 04.10.2017].

Wikipedia, https://pl.wikipedia.org/wiki/Wikipedia [dostęp: 03.10.2017].

Wikipedia: Głosowania, https://pl.wikipedia.org/wiki/Wikipedia:G\%C5\%82osowania [dostęp: 18.07.2017].

Wikipedia: Konsensus, https://pl.wikipedia.org/wiki/Wikipedia:Konsensus [dostęp: 05.10.2017].

Wikipedia: Size Comparisons, https://en.wikipedia.org/wiki/Wikipedia:Size_comparisons [dostęp: 29.07.2017].

Wikipedia:Statystyki: Wikipedyści według roku urodzenia, https://pl.wikipedia.org/wiki/Wikipedia:Statystyki/Wikipedy\%C5\%9Bci_wed\%C5\%82ug_roku_urodzenia [dostęp: 01.09.2017].

Wikipedia:Statystyki/Wikipedyści według wykształcenia, https://pl.wikipedia.org/wiki/Wikipedia:Statystyki/Wikipedy\%C5\%9Bci_wed\%C5\%82ug_wykszta\%C5\%82cenia [dostęp: 01.09.2017].

Wikipedia, Strona główna, https://pl.wikipedia.org/wiki/Wikipedia:Strona_g\%C5\%82\%C3\%B3wna [dostęp: 25.06.2017].

Wikipedia: Rozwiqzywanie konfliktów, https://pl.wikipedia.org/wiki/Wikipedia:Rozwi\%C4\%85zywanie_konflikt\%C3\%B3w [dostęp: 18.07.2017].

Wikipedysta: Lukas3, https://pl.wikipedia.org/wiki/Wikipedysta:Lukas3 [dostęp: 15.10.2017].

Wikipedysta:Monika, https://pl.wikipedia.org/wiki/Wikipedysta:Monika [dostęp: 15.10.2017].

Wikipedysta: Vuvar1, https://pl.wikipedia.org/wiki/Wikipedysta:Vuvar1 [dostęp: 15.10.2017]. 